\begin{tabular}{|c|c|c|c|c|c|c|}
\hline \multirow{4}{*}{ Impact Factor: } & ISRA (India) & $=3.117$ & SIS (USA) & $=0.912$ & ICV (Poland) & $=6.630$ \\
\hline & ISI (Dubai, UAE & $=0.829$ & РИНЦ (Russia) & $=0.156$ & PIF (India) & $=1.940$ \\
\hline & GIF (Australia) & $=0.564$ & ESJI $(\mathrm{KZ})$ & $=8.716$ & IBI (India) & $=4.260$ \\
\hline & JIF & $=1.500$ & SJIF (Morocco) & $=5.667$ & OAJI (USA) & $=0.350$ \\
\hline
\end{tabular}

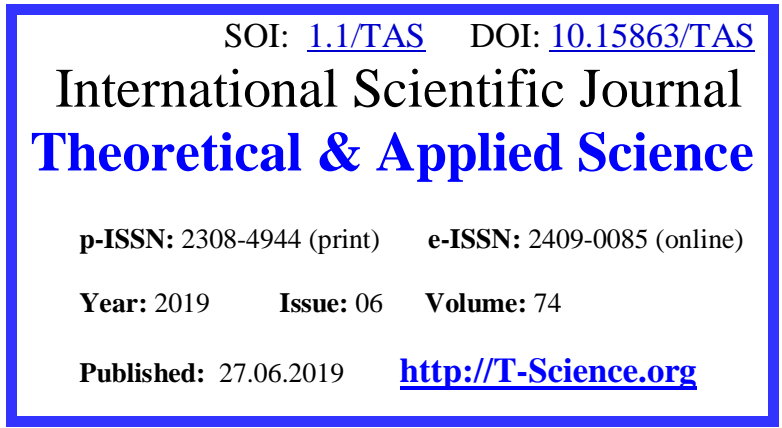

QR - Issue

QR - Article
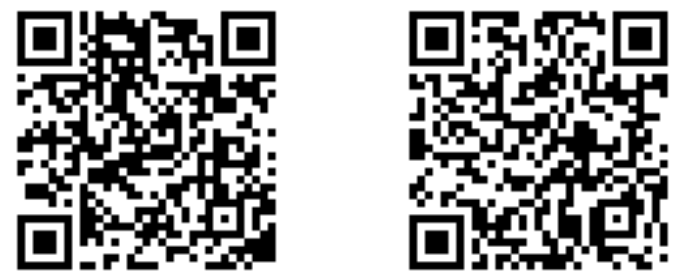

Abdurasul Abdullaev

the Islamic institute of Tashkent

Ph. D Candidate, Philosophical Science,

Senior Lecturer

\title{
RELIGIOUS TOLERANCE CULTURE IN UZBEKISTAN IS HERITAGE OF ANCESTORS
}

Abstract: Deep respect to languages, traditions, cultures and customs of other nations, keeping their entity, giving opportunity in carrying out cultural and spiritual demands, supporting them in all are the clear features of Uzbek tolerance. Exactly such kind of tolerance, patience gave the opportunity for saving enriching valuable examples of our culture, transmitting them through the tests of centuries. We can also see ideas propagating values concerning religious tolerance in the works of scholars of our country. We can find a lot of opinions about religious tolerance in Islamic sources written by scholars of our country. From this point of view religious tolerance of our nation living with representatives of other religion is not from needs occurred from necessity, but it has become the way of life. Uzbekistan is mentioned as historical inheritor of religious tolerance in the world community. Nevertheless, in this country from the ancient time religious tolerance was the main factor for the representatives of different religions that provided striving for welfare of the country. Road.

Key words: Central Asia, mosques, Uzbek, Hanafi (Imam A'zam) mazhab, Sunni, Christians, Jews, Great Silk

Language: English

Citation: Abdullaev, A. (2019). Religious tolerance culture in Uzbekistan is heritage of ancestors. ISJ Theoretical \& Applied Science, 06 (74), 529-531.

Soi: http://s-o-i.org/1.1/TAS-06-74-63 Doi: crossef https://dx.doi.org/10.15863/TAS.2019.06.74.63

\section{Introduction}

In Central Asia from the ancient time there was big attention and respect to the religious diversity. The first President of the Republic of Uzbekistan Islam Karimov wrote: "During thousands of years Central Asia was peaceful center of different religions, cultures and ways of life. Ethnic patience and tolerance became necessary natural standards for developing and surviving strikes of the life. Religious tolerance always served as specific shield against animosity in religious land. It opened the way for existing of different religions in one period and place together at one time, and also cooperation and unanimity among their carriers ${ }^{1}$.

During centuries mosques, churches and synagogues operated in big cities, and representatives of different nations and religions realized their religious deeds freely. During the most difficult periods of our history there were not religious conflicts among them, and it proves our nation has big experience concerning religious tolerance ${ }^{2}$.

Deep respect to languages, traditions, cultures and customs of other nations, keeping their entity, giving opportunity in carrying out cultural and spiritual demands, supporting them in all are the clear features of Uzbek tolerance. Exactly such kind of tolerance, patience gave the opportunity for saving enriching valuable examples of our culture, transmitting them through the tests of centuries, developing them, and also enriching them with significant results of other cultures. In turn it is proved by the history that such kind of attitude opened the way for accepting standards of behavior and spiritual values of our nation by neighboring people.

From the $9^{\text {th }}$ century Hanafi (Imam A'zam) mazhab of Sunni way of Islam was developed in today's Uzbekistan. It was for particular reason. Imam A'zam mazhab differs from others in giving freedom concerning other religions and local customs. $\mathrm{Al}$ 


\begin{tabular}{llllll} 
& ISRA (India) $=\mathbf{3 . 1 1 7}$ & SIS (USA) $=\mathbf{0 . 9 1 2}$ & ICV (Poland) & $\mathbf{= 6 . 6 3 0}$ \\
Impact Factor: & ISI (Dubai, UAE) $=\mathbf{0 . 8 2 9}$ & PUHЦ (Russia) $=\mathbf{0 . 1 5 6}$ & PIF (India) & $=\mathbf{1 . 9 4 0}$ \\
& GIF (Australia) $=\mathbf{0 . 5 6 4}$ & ESJI (KZ) & $\mathbf{8 . 7 1 6}$ & IBI (India) & $=\mathbf{4 . 2 6 0}$ \\
& JIF & $\mathbf{1 . 5 0 0}$ & SJIF (Morocco) $=\mathbf{5 . 6 6 7}$ & OAJI (USA) & $\mathbf{0 . 3 5 0}$ \\
\hline
\end{tabular}

Maturidi, Abul-Mu'in an-Nasafi and al-Marginani, who developed the doctrine of Hanafi mazhab, made great contribution to eliminate ideological supporting among Muslims, and keep stability of the way "ahli sunna va-1-jamaa". Not only great scholars, but also rulers of Middle Asia fought in this way ${ }^{3}$.

We can also see ideas propagating values concerning religious tolerance in the works of scholars of our country. The ideas concerning tolerance mentioned in the works of the great scholar, the founder of Maturidi way of aqida Abu Mansur alMaturidi (870-944) can be example for this.

Also, Maturidi in his work famous in the Islamic world on the commentaries to the Qur'an "Ta'vilat ahli sunna" in the surah "Hajj", ayah 40 states firmly: "It is forbidden to destroy churches and synagogues. That's why, they still exist in the Islamic countries. On this matter there is no controversy among scholars". ${ }^{4}$

The scholar and mufassir from Samarkand Abu Lays as-Samarqandi in his book on the commentaries to the Qur'an "Bahr al-ulum" in the commentary to the surah "Mumtahana", ayahs 8-9 wrote: "Keep relationship with the representatives of other religions who are not at war with you, and be in just attitude to them" .

One of the well-known scholars and mufassirs in Mawarannahr Abul Barakat an-Nasafi in his famous book in the Islamic world "Madorik at-tanzil" gives the commentary to above mentioned ayahs as follows: "Show respect for representatives of other religions and do them good in words and deeds"6.

In the works of well-known Sufi al-Hakim atTermizi positive opinions are given concerning some classes of Christians? ${ }^{7}$. Al-Maturidi states that Christians are closer to Muslims in spirit and they are closer to be in friendly relations ${ }^{8}$. Abul Barakat anNasafi states that Christians are close to Muslims in spirit, and there are faithful and modest, that is learned among them. He also mentions that it doesn't matter who owns knowledge, it will lead to good.

We can find a lot of opinions about religious tolerance in Islamic sources written by scholars of our country. From this point of view religious tolerance of our nation living with representatives of other religion is not from needs occurred from necessity, but it has become the way of life. We can see it in analyzing

\footnotetext{
${ }^{3}$ Hasanov A. Uzbekistan is the land of tolerance. // Contribution of Uzbekistan to development of Islam civilization. Collection of lectures and congratulations of international conferences // T.: Publications of Republic scientific educational center named after Imam Bukhari, 2007. p. 373

${ }^{4}$ Abu Mansur al Moturudi. Ta'vilotahli Sunnah. - Beirut:

Muassasaar-risala, 2004. Vol.III. p. 376

${ }^{5}$ Abu Lays as Samarqandi. Bahr al ulum. Beirut: Dor al kutub,

1993. Vol.III. p. 353

${ }^{6}$ AbulBarakot an Nasafi. Madorik at Tanzil. Beirut: Dor al kutub. Vol.II. p. 674
}

ancient and modern states of attitude to Jews and Christians in our country.

From the past Central Asia is considered the point that developed the opportunity for different cultures to come across, their influence and enriching. Certainly, Great Silk Road connecting the East with the West that went through Central Asia created conditions for this.

At the beginning of the $15^{\text {th }}$ century the ambassador of Castile in the palace of Temur stated, that Temur had gathered representatives of different religions and showed respect for them. As it is mentioned in other sources, one of the sons of Temur was responsible for supporting Christians and relationships among Christian countries ${ }^{9}$.

At the beginning of the $18^{\text {th }}$ century because of political processes occurred in Central Asia Jews divided into Iran, Afganistan, Khiva, Kokand and Bukhara groups. In the second half of the $19^{\text {th }}$ century occupying one of the parts of Central Asia by Russian empire resulted dividing of Jews again into Turkistan and Bukhara groups. As Jews of the continent lived in the territory of Bukhara emirate, they were known with the name "Bukhara Jews", but the main part of them lived in Samarkand ${ }^{10}$.

It is known, that Central Asian Jews were so embodied with local people that they spoke PersianTurkic languages mixed. The main reason is that Jews came to Central Asia through Iran, they used Torah in Persian language until recently, and they mixed partly with local people. In spite of the fact that religious factors and hard conditions in the past caused Jews to live separately from all, it was seen their becoming close with the local people. As a result, Jews language changed into Samarkand-Bukhara dialect of Tajik language. Also, elements of Uzbek-Tajik people appeared in their cloths, meals, traditions, musical culture and life style.

But, mixing of Jews with local people didn't occur, because religious relating didn't allow it. Religious belonging played the role of ethnic differentiating ${ }^{11}$.

There were schools, periodicals and special publications of Jews in Hebrew. In 1932 there was founded Jews theater in Samarkand. Basing on the idea "Mixing of nations in the future" Communistic

\footnotetext{
${ }^{7}$ Al Hakim at Tirmizi. Navodir al usul. Cairo: DorarRayyon, 1988. p. 222-227

${ }^{8}$ Abu Mansur al Moturidi. Ta'vilotahlisunna. Beirut:

Muassasaarrisala, 2004. Vol.II. p. 60

${ }^{9}$ History of religions of Central Asian nations / edited by Sh. Yavkachev. - T.: TSOI. 2006. p. 67

${ }^{10}$ History of religions of Central Asian nations / edited by Sh.

Yavkachev. - T.: TSOI. 2006. p. 61

${ }^{11}$ History of religions of Central Asian nations / edited by Sh

Yavkachev. - T.: TSOI. 2006. p. 58-59
} 


\begin{tabular}{llllll} 
& ISRA (India) $=\mathbf{3 . 1 1 7}$ & SIS (USA) & $=\mathbf{0 . 9 1 2}$ & ICV (Poland) & $=\mathbf{6 . 6 3 0}$ \\
Impact Factor: & ISI (Dubai, UAE) $=\mathbf{0 . 8 2 9}$ & PUHL (Russia) $=\mathbf{0 . 1 5 6}$ & PIF (India) & $=\mathbf{1 . 9 4 0}$ \\
& GIF (Australia) $=\mathbf{0 . 5 6 4}$ & ESJI (KZ) & $=\mathbf{8 . 7 1 6}$ & IBI (India) & $=\mathbf{4 . 2 6 0}$ \\
& JIF & $\mathbf{1 . 5 0 0}$ & SJIF (Morocco) $=\mathbf{5 . 6 6 7}$ & OAJI (USA) & $\mathbf{0 . 3 5 0}$ \\
\hline
\end{tabular}

Party cancelled the opportunity for nations small in numbers to get education in their own language. Also, it was cancelled to teach in Jews language and conduct cultural activity.

In 1991 after Uzbekistan achieved Independence there were given all conditions for all religions to be believed freely. Nowadays in our country national cultural centers of Jews of Bukhara and Europe were founded, and eight Jews religious groups are operating.

During the centuries Islam created big conditions for social-economic and cultural developing. Also, in eastern countries under the influence of Islamic teachings cultures of different nations became close to one another, developed synthesis of civilization. As a result, different nations are keeping national entity, religious belief, spirit and big heritage during thousands of years. Concerning these friendly relationships Islam Karimov wrote: "Living of Muslims and Christians in the territory of Uzbekistan unanimously is the valuable sign of spiritual friendship and the best example of tolerance to all representatives of other religions" $" 12$.
Thanks to Independence in addition to all spheres of social life there were serious reforms in the attitude to believers. There are all bases for this. At first, there are all conditions for religious scholars in participating actively in social life. In the second, until recently interest and striving for knowing religious values and studying them assessed negatively. But nowadays, all conditions are given to keep and develop religious customs, traditions and values.

In our country organizations concerning Islam and other fifteen religious confessions are operating nowadays. Each person, society and nation should realize that humanity consists of different cultures and should respect them. As there is no peace without tolerance, so there is no development without peace.

Uzbekistan is mentioned as historical inheritor of religious tolerance in the world community. Nevertheless, in this country from the ancient time religious tolerance was the main factor for the representatives of different religions that provided striving for welfare of the country. It continues so now too.

\section{References:}

1. AbulBarakot an Nasafi (n.d.). Madorik at Tanzil. Vol.II. (p.674). Beirut: Dor al kutub.

2. Abu Mansur al Moturidi (2004). Ta'vilotahlisunna. Vol.II. (p.60). Beirut: Muassasaarrisala.

3. Abu Mansur al Moturudi (2004). Ta'vilotahli Sunnah. Vol.III. (p.376). Beirut: Muassasaarrisala.

4. Abu Lays as Samarqandi (1993). Bahr al ulum. Vol.III. (p.353). Beirut: Dor al kutub.

5. Achildiev, A. (2004). National ideology and international relationship. (p.92). Tashkent: Uzbekistan.

6. Al Hakim at Tirmizi (1988). Navodir al usul. (pp.222-227). Cairo: DorarRayyon.

7. Hasanov, A. (2007). Uzbekistan is the land of tolerance. Contribution of Uzbekistan to development of Islam civilization. Collection of lectures and congratulations of international conferences. (p. 373). Tashkent: Publications of Republic scientific educational center named after Imam Bukhari.

8. (2006). History of religions of Central Asian nations. edited by Sh. Yavkachev (Eds.). (p.67). Tashkent: TSOI.

9. (2006). History of religions of Central Asian nations. edited by Sh. Yavkachev (Eds.). (p.61). Tashkent: TSOI.

10. (2006). History of religions of Central Asian nations. edited by Sh. Yavkachev. (pp.58-59). Tashkent: TSOI.

11. (2000). Ideology of national sovereignty: Main concept and tendencies. (p.61). Tashkent: Uzbekistan.

${ }^{12}$ In the way of spiritual development. - T.: Uzbekistan, 1998. 